\title{
Translation of Islamic Arabic Poetry: A Two-Stance Methodological Framework
}

\author{
Ahmad Mustafa Halimah ${ }^{1}$ \\ ${ }^{1}$ Associate Professor of Applied Linguistics and Translation Studies, Department of English Language, College of \\ Arts, King Faisal University, Saudi Arabia \\ Correspondence: Ahmad Mustafa Halimah, King Faisal University, Saudi Arabia.
}

Received: August 21, 2021

doi:10.5430/wjel.v11n2p152
Accepted: September 7, $2021 \quad$ Online Published: September 22, 2021

URL: https://doi.org/10.5430/wjel.v11n2p152

\begin{abstract}
This study investigates whether it is possible to translate Islamic Arabic poetry, as a universal literary religious genre, into English to a high level of quality. A global-local translation framework (Halimah, 2020) is applied to the translation of Imam Ashshafi'ee's poem “"الرضا بقضاء اللهاء" “Accepting Fate with Pleasure” into English, where a methodological collaboration between a bilingual translator and an English poet manifests a two-stance methodological framework. The results, along with the qualitative and quantitative analysis of poetic extracts used in this paper, indicate that this framework has resulted in improving the quality of Islamic Arabic poetry translation. The translated materials proved to be 'novel and appropriate', achieving a very high $90 \%$ of approximation of the original text against ACNCS criteria. This framework can also be applied by translators of other literary and non-literary texts to bring more structure and clarity to the discipline of translation.
\end{abstract}

Keywords: poetry, translation, global, local, framework, ACNCS criteria

\section{Introduction}

The beautiful nature of poetry is that it means different things to different people. For Halimah (2017:86), it is "a representation of intense feelings and spontaneous flow of different ideas written or spoken in a distinctive style with rhythm and rhyming sounds". Although we generally tend to read poetry out of a desire for entertainment of some kind, we still take to reading it seeking a sense of emotional sentiment and even level of spiritual serenity. In the case of Islamic Arabic poetry, it is a sublime piece of art that reminds its readers of their purpose in this life, the miracles of the Creator and the absolute truth of His Oneness.

As with other literary text types, there are a variety of topics and themes under the umbrella of poetry. The most renown is romantic verse but other genres such as war poetry, national poetry and, the topic of our current study, Islamic poetry, carry their own significance and weight too. A good way of clearly defining Islamic Arabic poetry as its own unique sector of this text type would be 'poetic verse penned with an influence from the Islamic beliefs, ideals and culture that conveys a message or expression of the religion's ideals and culture'.

With regard to translation, we need to first ask ourselves whether poetry can be translated or not. A straightforward answer to such a central question would be 'yes' as it can obviously be translated; translated poetry constitutes such a large part of the literature of most languages and cultures. Omar Khayyam poetry in English is a good example. Despite this, however, there is an opposite view held which believes that poetry translation is difficult or even impossible. This is probably due to the assumption that translated poetry should be poetry in its own right; poetry is not only difficult and ambiguous but also represents a special and complex relationship between form and meaning (Boase-Beier, Jean: 2011 in Baker \& Saldanha, eds.).

Thus, this paper is an attempt to answer whether the translation of Islamic Arabic poetry as a universal literary/religious genre into English is possible or not. To achieve this goal, a two-stance translation methodological framework (Halimah, 2020) will be applied to the translation of Imam Ashshafi'ee's poem titled "الرضا بقضاء الله" "Accepting Fate with Pleasure" into the English Language, where a methodological collaboration between the author, a bilingual and bicultural translator (henceforth referred to as 'the translator') and a native English poet (henceforth referred to as 'the poet') is used as a manifestation of this framework. 


\subsection{Research Question}

The following question was formed to investigate whether the translation of Islamic Arabic poetry as a universal religious genre into English is possible.

- Is the application of a collaborative global-local translation framework to the translation of Islamic Arabic poetry into English possible? And if it is, what approximation of the original text is achievable in translation?

\section{Theoretical Background}

The translation of poetry is a very complicated process; some would say 'dismantle the original poem and build' the translation and others would say 'make a close reading and writing of the source text' and then be creative and inventive in your translation (Boase-Beier 2011:196). David Pendlebury (2005:15) suggests a Two-Stage Approach: where the translator 'produces a draft translation of the original that is as literal and accurate as possible' and then translates 'this draft, with only minimal reference to the original'. There seem to be several different ways of translating poetry, but most poetry translators aim to produce a translation that works as poetry in the target language. Their goal is for it to have an equivalent effect on the translated text reader as the original poem on the source text's audience.

Scott (2000: 251) with the "central preoccupation" of translation as a servant of self-expression rather than of pedagogy, chooses free verse as the basis for equilibrating all the constituents in poetry translation. In his article "Teaching Translation of Poetry", Halimah (2015) promotes a collaborative approach to the translation of poetry. The main idea of this approach is based on a collaborative mechanism where a translator and a poet, native in the target language, work together to produce a translation which achieves the highest level of approximation of the original text in terms of accuracy, clarity, naturalness, communicative effects and stylistic features.

With regard to the translation of religious poetry in general, and Islamic Arabic poetry in particular, the process is often challenging and complicated. Although a substantial amount of Islamic Arabic poetry has been translated into several languages, which are mainly spoken in Muslim countries such as Pakistan, Indonesia and Bangladesh, the great poem "Accepting Fate with Pleasure" by Imam Ashshafi'ee has not yet been sufficiently translationally and methodologically researched and studied. Dikins etal. (2002:90), for example, only makes use of the first two lines of the poem to explain "the special set of features of traditional Arabic poetry and its versification which would cause specific translation challenges." In their analysis of the translation of first two lines, authors stressed on the issues of 'appropriateness and practicality' as extremely important elements of poetry translation. They, however, overlooked the significance of the religious message implied in the content of the poem and its spiritual denotations and connotations as an Islamic masterpiece of poetry. Their use of a strict literal method in the translation deprives TL readers of not only the Islamic cultural dimensions of the original poem but also of its religious and spiritual communicative effect enjoyed by the original SL readers. The lines they used were translated as follows:

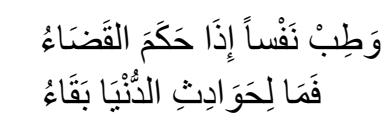

Let the days do what they will,

Don't be concerned at the night event,

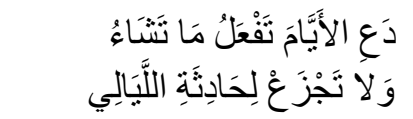

and be of good cheer when fate judges

for the world's events have no permanence.

The following translations illustrate the problems and difficulties an Islamic Arabic poetry translator may encounter in conveying not only the religious implicatures of a poem, which was written more than twelve hundred years ago, but also in transferring the poetic form implied in the rhyming and rhythm of the line. The rhyming and versing in a poem tend to be equally problematic in the translation of poetry. How to achieve equivalence with accuracy and clarity of meaning supported by rhythmic and stylistic elegance is not only of paramount importance in the translation of poetry but an on-going challenge facing literary translators.

Evaluate the following possible translations of the first of the above two lines of poetry, applying the grading criteria of accuracy, clarity, naturalness, communication and style (henceforth ACNCS) explained below and then decide which one sounds most appropriate and achieves the highest level of approximation of the original text.
A. Let the days do what they want
and be satisfied with whatever that might happen
B. Let the days do what they want
and be happy with whatever fate has ruled 

C. Let life takes its toll
whether you rise or fall
D. Let the days take their toll
and be happy whether you rise or fall
E. Let life takes its toll
and be happy whether you rise or fall
F. Let the days take their course,
and accept the map of fate.

Regarding to the criteria governing the translation of poetry, Bassnett, in her book on Translation Studies (1980), gives a brief survey of poetry translation, extending from a structural approach where the linguistic and formal structures of the original poem form the basis of the criteria used by the translator. She mentions the seven different strategies suggested by Andre Lefevere (1975) such as 'Phone mic translation, literal translation, metrical translation, poetry into prose, rhymed translation, blank verse translation and interpretation', criteria of length, shape, organisation of lines and tone of poetry translation and discoursal translation giving priority to conversational tone and mood to principles of interpretation and accuracy of translation.

There are certain constraints we must consider when translating any literary text in order not to lose sight of the main purpose of our translation or make the translated text (TT) read as strange and irrelevant. These constraints can be expressed in terms of criteria or a checklist we could always refer to while we are engaged in the process and product of the translation. In order of importance, they are listed in appendix A.

As a working definition, 'Islamic Arabic translation' is used here to refer to the process of transferring Islamic Arabic Poetry with the utmost accuracy, clarity, naturalness, communicative effects and stylistic features of the source text into a target religious text in another language. Achieving such a challenging task falls on the shoulders of the religious translator who needs to take the ACNCS criteria as the main guidelines to processing and producing a translated Islamic text that is inspirationally novel, stylistically right and beautifully appropriate.

Having made those references and being a practitioner interested in the translation product of religious poetry, I adopted a product collaborative global-local methodological framework to translation while taking into account any cultural and stylistics constraints. This framework is based on Halimah (2020), where the participants took up a global stance and used a literal/faithful translation method (Newmark, 1988), that would emphasise the Arabic language and Islamic culture, and then decided on Venuti's Foreignisation Approach (1995) to enable them to achieve the maximum degree of equivalence of the original text possible. Their aim was to produce a TT that would affect the TL reader in regard to meaning, register, context and culture specific terms. This two-stance mechanism was then used for analysis and discussion.

Any collaborative global-local translation of the meanings of the poetry is accepted if it does not violate any of the principal cultural and stylistic criteria of Islamic poetry translation. To achieve such an acceptable version of Islamic poetry in English, the translated text should attain maximum approximation in equivalence and the communicative purpose of the text should be conveyed in an appropriate style without violating any cultural and poetic features of the poem. A translation of this standard should naturally endeavour to transfer the linguistic, social, cultural, religious and stylistic associations and connotations of the original text, in addition to its rhythmic and rhyming impact on the TL receptor, if possible, into English.

\section{Methodology}

The aim of this study is to investigate the effectiveness of the application of a collaborative global-local translation framework to the translation of Islamic Arabic poetry into English as a translation mechanism to help translators, teachers and students of translation improve the quality of their translation of Islamic Arabic poetry into English. To "الرضا بضضاء الله، " / "Accepting Fate with Pleasure" into the English Language. The translator translated the poem and produced version A as a first draft then sent it off to the poet who then provided the author with a modified upscaled Version B.

\subsection{Participants}

The translator and poet formed the participants for this study. The translator's native tongue was Arabic, and his goal was to translate the poem from Arabic into English. The poet had a modest knowledge of Arabic and her goal was to convert a draft prose translation of Imam Ashshafi'ee's poem titled "الرضا بقضاء الله / "Accepting Fate with Pleasure" into a well-formed English poem.

\subsection{Evaluators}

The translator and poet participated, collaborated, discussed, and assessed the translated versions of the poem, applying the same grading criteria of ACNCS as summarised below. (See appendix A for more details on these 
criteria).

1) Accuracy: Refers to the ability to faithfully convey the exact and precise meanings of the source text to the target text.

2) Clarity: Refers to intelligibility without causing the translated text reader to exert any extra mental effort to understand what is meant by the content of the TT.

3) Naturalness: Refers to the translator's ability to apply appropriate natural forms and norms of the Target Language to the source text which he/she is translating, be these forms and norms linguistic, sociolinguistic, psychological, sociocultural, religious or communicative.

4) Communication: Refers, in the translation of poetry, to the ability of the translator to transfer not only the meaning but also the emotional aspects of the ST to the target reader as effectively and faithfully as they are communicated to the ST readers in the first place.

5) Style: Refers, in literary texts, to the linguistic devices the author uses in their writing to tell a narrative, to describe events, objects and characters or to voice out their views and ideas in the manner of their choosing, be it formal, informal, casual or archaic. It refers to the ability to transfer the stylistic features of the ST to the target text with the same stylistic force used by the ST writer or speaker (Halimah, 2015:35).

Due to the limited time, space and scope of this paper, only three versions of the translated poem will be analysed and discussed.

\subsection{Material}

After reviewing and considering a number of Arabic religious short poems, Imam Ashshafi'ee's poem, titled “ الرضا "بقضاء الله / "Accepting Fate with Pleasure", was selected as an example of Islamic Arabic poetry to be translated from Arabic into English through a collaborative global-local translation framework. This poem was not only chosen because of its popularity among Muslims all over the world, but also because it stands as an example of a giant Islamic poet and jurist with massive knowledge, experience and great wisdom.

The poem itself revolves around a religious theme in which Ashshafi'ee calls the reader for an absolute surrender to no one but to Allah. It is an expression of his firm belief and faith in the submission to the ruling of Allah and advocacy for the acceptance of fate with pleasure. Ashshafi'ee uses beautiful imagery, poetic rhyming and rhythm, powerful expressions and imagination to support his thoughts and beliefs. For him, what makes oneself good, kind, contented, satisfied and happy is one's surrender to the ruling of Allah and one's acceptance of his/her fate with pleasure. It is in essence the poet's invitation to have strong faith, patience, tolerance, forgiveness and generosity.

\subsection{Procedure}

The translator and the poet met several times via videoconferencing and agreed to collaboratively translate the poem. The poem was read and its difficult terms were explained and discussed online. Many discussions on different linguistic, stylistic and cultural aspects of the poem were debated and the translator's personal interpretations of the poem were shared with the poet. Doing this minimised the difficulties encountered by the participants and, in terms of the interpretation and understanding of the spirit of the poem, helped them be better prepared. This consequently enabled them to reproduce an Islamic English recreation of the religious denotations and connotations as well as the spiritual message embedded in the poem.

With regard to the translating process of the Islamic poem and in a similar manner to other types of religious genres and text-types, the participants agreed to firstly take up a global stance and use a literal/faithful translation method that would emphasise the Arabic language and Islamic culture. They then decided on a foreignisation translation local approach which would enable them to achieve a maximum degree of equivalence of the original text with an effect on the TL reader in meaning, register, context and culture specific terms. This two-stance mechanism was used for analysis and discussion. At a micro level, different and various strategies were borrowed from translation theory and linguistics to serve as tools to analyse and solve practical problems in the translation of the poem. Halimah's (2015) criteria for assessing the quality of translated versions of the poem, along with Baker's (1992) levels of equivalence, were used to add value to the methodology adopted.

The sample collaboration of the translator and the poet in this study involved not only initial understanding, interpretation and discussion of the Source Text, but also alternation of the Translated Text among themselves. In other words, the translator produced the first draft version A of the poem using a very strict literal method of translation and then sent it off to the poet in both Arabic and English formats. The poet then took up the draft produced by the translator and spent some time working on improving it and trying to approximate it as much as 
possible to the original text before returning it to the translator. The translator revisited version B and sent it off again to the poet to make some changes and improve it. The poet did so and eventually send it back to the translator who again made some changes and improvements to produce version $\mathrm{C}$ as a final version. After this laborious collaborative work, they met again online to agree on the final copy of the translated text. Although it may sound quite time consuming and laborious, the results it produced, in terms of the quality of the translated text and in achieving 'equivalence' in translation and the ACNCS criteria, were worthwhile.

\section{Results and Discussion}

The question now is how can we translate a poem of such religious status with such sublime purpose, function and powerful linguistic and stylistics features? How can we transfer the social associations, cultural connotations and historical reference implied in the poem? How can we render the religious, spiritual and emotional message along with the intentions of a giant poet like Ashshafi'ee who lived more than twelve hundred years ago?

In translating our sample poem below "الرضا بقضاء الله" / "Accepting Fate with Pleasure", taken from the Diwan of Imam Ashshafi'ee Poetry (2007:27), a two-stance translation methodological framework with the ACNCS criteria has been used as a governing body of rules and guidelines for both the translator and the poet. The collaborators worked together to produce three versions of the translation of this Islamic Arabic poem. During the process there was a continuous consultation between them, where they started with version (A) as a strict literal translation, then rewrote it and improved on it in version (B), before producing it as a 'poem to poem' translation in version (C) with an $90 \%$ approximation of the original text. This three-step can be seen below.

\begin{tabular}{|c|c|}
\hline \multicolumn{2}{|c|}{ الرضا بقضاء الله } \\
\hline وَطِبْ نَفْساً إذذا حَكَمَ القَضَّاءُ & دَع الأَيَّاَ تَفْعَلُ مَا تَثَثَاُُ \\
\hline 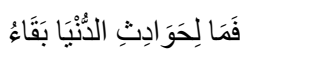 & 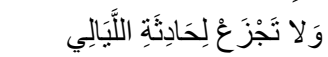 \\
\hline 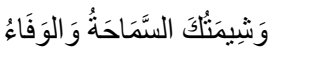 & وَكُنْ رَجُلاً عَلَى الأَهْوَالِ جَلْداً \\
\hline وَسَرَّكَ أَنْ يَكُونَ لَهَا غِطَاءُ & 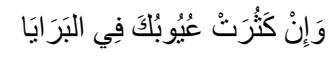 \\
\hline يُنَغَطِيِهِ كَمَا قِيَلَ السََخَاءُ & 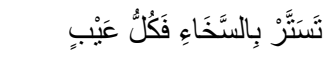 \\
\hline 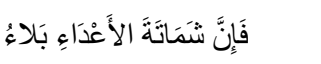 & 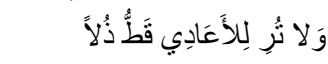 \\
\hline فَمَا فِي النَّارِ لِلِظَّمَاْنِ مَاءُ & لا تَزْرج السَََّاحَةَ مِنْ بَخِيلٍ \\
\hline وَلَيَّنَ يَزِيدُ فِي الرِّزْفِ العَنَاءُ & 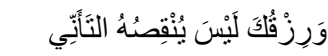 \\
\hline وَلا بُؤُسُ عَلَيْكَ وَلا رَخَاءُ & خ حُزْنِن يَدَوُجُ وَلا سُرُورُ \\
\hline فَأَنْتَ وَمَالِلِكُ الدُنْنَّا سَوَاءُ & ا مَا كُنْتَ ذَا قَلَبِ قَتُوع ع \\
\hline فَلا أَرْضُّ تَقِيهِهِ وَلا سَمَاءُ & نْن نَزَلَتُ بِسَاحَتَهِهِ المَنَايَا \\
\hline إذذا نَزَلَ القَضَّاء ضَتَقَ الفَضَنَاءُ & 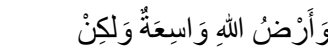 \\
\hline 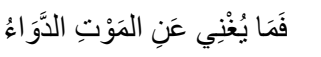 & مَ تَنَخْرُ كُلَّ جِينٍ \\
\hline
\end{tabular}

\section{Step One}

As a starting point, the translator read this great universal poem three times, explained its difficult terms and discussed its linguistic, cultural, religious, stylistic aspects with an Arabic specialist, when necessary, to build a good understanding and interpretation of the poem as a ST. This helped him minimise the possible difficulties he could encounter and helped him be better prepared in terms of accurate understanding and interpretation of the mood and spirit of the poem. Consequently, he then felt confidently able to produce an English recreation of not only the linguistic, cultural, religious, and stylistic elements in the poem but also the feelings, emotions and even the spiritual dimensions embedded in it.

\section{Step Two}

After the translator had successfully taken up step one, he started making his first translation draft/s of the above poem. Drafting tends to take different shapes and forms but for clarity a table of two columns was used that allowed the Arabic text to be placed on the right and its English draft equivalents on the left. Due to the specific variation nature of translation and to make its drafts easily understood by the poet, the draft below provided the collaborator with more than one translation and or /explanation of certain lines. This was so that they would be able to grasp the 
whole poem as one unit of meaning, cohesion and coherence in form and content. Such a skeleton for the translator's drafting process is a good structure to use as it is clearly set out. The first draft of the translated poem looked as in table 1 version A below:

\section{Table 1. Version A}

\begin{tabular}{|c|c|}
\hline Content with Allah's Ruling & الرضا بقضاء الله \\
\hline $\begin{array}{l}\text { - Let the days do whatever they want and be happy with } \\
\text { whatever fate ruled. } \\
\text { - Accept the fate of the days and be content with whatever the } \\
\text { results. } \\
\text { - Let life takes its toll and be happy whether you rise or fall }\end{array}$ & وَطِبْ نَفْساً إذذا حَكَمَ القَضَّاءُ \\
\hline $\begin{array}{l}\text { - Despair not by life's events they will cease to be as all worlds' } \\
\text { events. } \\
\text { - Don't let the adversity affects you. It will not stay long with } \\
\text { you. }\end{array}$ & فَفَا لِحَوَ ادِثِ الدُنْيًَا بَقَاءُ \\
\hline $\begin{array}{l}\text { - Be a man of all endurance and your custom is loyalty and } \\
\text { tolerance } \\
\text { - Be a strong man in adversity and let the tolerance and honesty } \\
\text { be your quality }\end{array}$ & 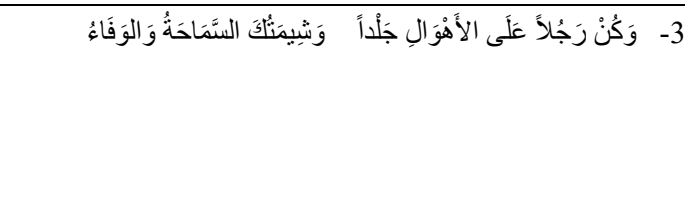 \\
\hline $\begin{array}{l}\text { - If you have so many blemishes and want to cover up such } \\
\text { blemishes } \\
\text { - If your faults by the time increase cover them by goodness and } \\
\text { charities } \\
\text { - If your faults become too many in the eye of people and you } \\
\text { wish that they were to be concealed. }\end{array}$ & 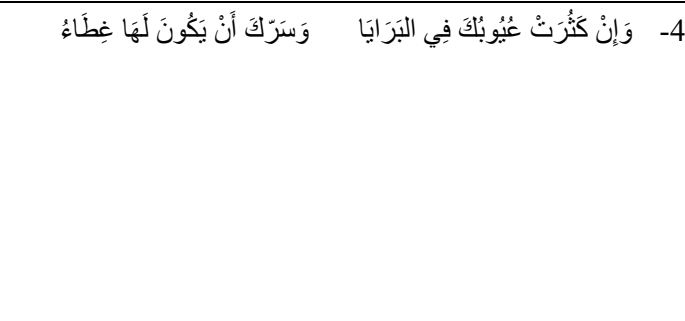 \\
\hline $\begin{array}{l}\text { - Hide under kindness and generosity allegedly all demerits can } \\
\text { be covered by kindness } \\
\text { - Then note that kindness convers all faults how many faults are } \\
\text { kept hidden by kindness? }\end{array}$ & 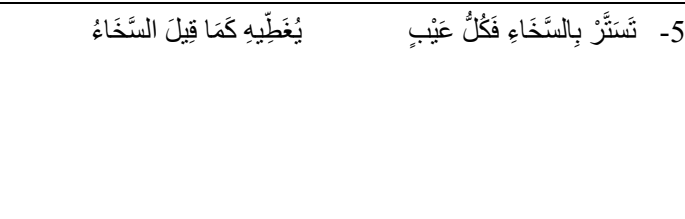 \\
\hline $\begin{array}{l}\text { - Never show your enemies any kind of humiliation, because } \\
\text { the enemies' laughing at your misfortune is a } \\
\text { plague/infliction/ordeal /curse/. }\end{array}$ & فَاِنَّ شَمَانَةَ الأَعْدَاِ بَلاءُ \\
\hline $\begin{array}{l}\text { - And do not seek/hope/ wish grace/tolerance/ forgiveness from } \\
\text { a stingy/ a miserly/mean, as there would be no water for one } \\
\text { who is thirsty in fire. }\end{array}$ & 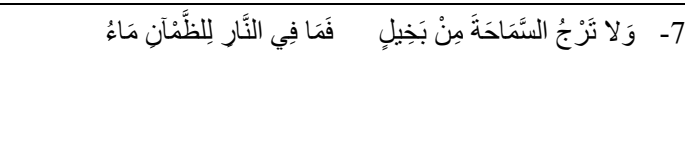 \\
\hline $\begin{array}{l}\text { - Your livelihood is not lacking in prudence/forethought } \\
\text { - /caution, and it does not increase in hard labour. }\end{array}$ & وَلَيَّنَ يَزِيدُ فِي الرِّزْْ العَنَاءُ \\
\hline $\begin{array}{l}\text { - Neither sorrow/sadness, nor pleasure/happiness, nor misery } \\
\text { upon you, nor prosperity will last forever. }\end{array}$ & 9- وَلا حُزْنُ يَدُومُ وَلا سُرُورٌ \\
\hline $\begin{array}{l}\text { - If you have the heart of contentment, then you and the king of } \\
\text { this world are the same. }\end{array}$ & 10- إذا مَا كُنْتَ ذَا قَلَبِ قَتُوع \\
\hline $\begin{array}{l}\text { - And when death/ordeals descend on Square/quarters, land of } \\
\text { anyone, neither the earth nor the heaven could protect him. }\end{array}$ & 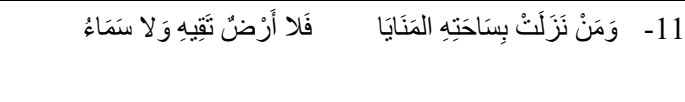 \\
\hline
\end{tabular}




\begin{tabular}{|c|c|c|c|}
\hline $\begin{array}{l}\text { - The land of Allah/God is vast, but when the judiciary } \\
\text { descends, space is narrowed/tight/too crowded. }\end{array}$ & إِذَا نَزَلَ القَضَّاء ضَاقَ الفَضَاءُ & وَأَرْضُ اللهِهَ وَاسِعَةُ وَلكِنْ & -12 \\
\hline $\begin{array}{l}\text { - Let the days breach/break the covenant every now and then, } \\
\text { medications/treatment will never stop/take away death when } \\
\text { the time comes. }\end{array}$ & فَسَا يُغْنِي عَنِ المَوْتِ الََََّّاءُ & دَعِع الأَيَّامَ تَتَغْرُ كُلَّ حِينٍ & -13 \\
\hline
\end{tabular}

With regard to the global stance and the method used, the translator employed a strict literal/faithful method to enable him to emphasise the source language, source culture and source religious message quite effectively. As for his local stance, the translator used two: a 'foreignising approach' and a 'collaborative approach' which allowed him to convey the foreign elements and features implied in the poem and seek collaboration with an English poet. The criteria governing his translation were an ACNCS evaluation as well as criteria of length, shape, organisation of lines and tone of poetry translation, taking into account the equation of equivalence. As the data is in two languages, the translator evaluated the translated texts allocating a five-point scale: the set of the ACNCS criteria. The grading scale was set to be out of 'five' with five being the maximum grade attainable when full equivalence of a particular section was achieved.

\section{Step Three}

After the translator had taken up step two successfully, he contacted the poet and asked her whether she could convert his draft translation/s of the poem above into English while observing all the criteria's constraints. An in-depth discussion of the translation of the poem was held with the poet to make sure she understood every detail of the poem whether it was linguistic, cultural, rhetorical, stylistic, religious or even spiritual. He revised the translation drafts more than once and the process was like travelling on an exploratory journey; they began it together and finished it together. Once the translation drafts had been explained, the poet then produced her first translation of the poem, table 2 version B below:

\section{Table 2. Version B}

\begin{tabular}{|c|c|c|c|}
\hline $\begin{array}{l}\text { Grade } \\
\text { Max:5 }\end{array}$ & “Accepting Fate with Pleasure". & الرضا بقضاء الله & \\
\hline 4 & $\begin{array}{l}\text { 1.Let the days take their course. } \\
\text { 2. And accept the map of fate. }\end{array}$ & وَطِبْ نَفْساً إذذا حَكَمَ القَضََاءُ & 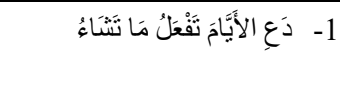 \\
\hline 5 & $\begin{array}{l}\text { 3.Don't mourn the distress of the night, } \\
\text { 4.Its trials will pass come daylight. }\end{array}$ & فَمَا لِحَوَ ادِثِ الدُنِْْا بَقَاءُ & 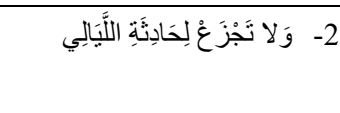 \\
\hline 3 & $\begin{array}{l}\text { 5.Be a man strong in adversity, } \\
\text { 6.With qualities good and great; } \\
\text { 7.A man of tolerance and integrity } \\
\text { 8.Who is honest in every trait. }\end{array}$ & وَشَيمَتُلكَ السَّمَاحَةُ وَالوَفَاءُ & 3- وَكُنْ رَجُلاً عَلَى الأَهْوَ الِِ جَلْداً \\
\hline 5 & $\begin{array}{l}\text { 9.And if your faults become too many, } \\
\text { 10. And you wish to conceal your shameful tale }\end{array}$ & وَسَرَّكَّ أَنْ يَكُونَ لَهَاغِطَاءُ & 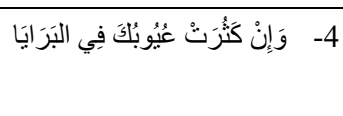 \\
\hline 5 & $\begin{array}{l}\text { 11. Cloak them with sheer kindness, } \\
\text { 12. For much has it hidden in its veil. }\end{array}$ & يُغَطِيّيهِ كَمَا قِيلَ السَّذَاءُ & 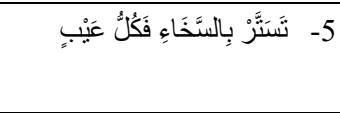 \\
\hline 4 & $\begin{array}{l}\text { 13. Never let your indignity to enemies seen, } \\
\text { 14. Them mocking your dishonour is a curse }\end{array}$ & فَإِنَّ شَمَانَةَ الأَعْدَاءِ بَلاءُ & 6- وَلانُر لِلأَعَادِي قَطُ ذُلاً \\
\hline 5 & $\begin{array}{l}\text { 15. And seek no forgiveness from the mean, } \\
\text { 16. In flames the parched do die of thirst. }\end{array}$ & فَمَا فِي النَّارِ لِلظَّمْاَنْ مَاءُ & 7- وَلا نَرْجُ السَّمَاحَةَ مِنْ بَخِيلٍ \\
\hline 4 & $\begin{array}{l}\text { 17. Your provision is written on destiny's page } \\
\text { 18. Its amount in stone, toil as you may }\end{array}$ & وَلَيَسَنَ يَزِيدُ فِي الرِّزْقِ العَنَاءُ & 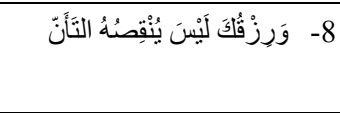 \\
\hline
\end{tabular}




\begin{tabular}{|c|c|c|c|}
\hline 3 & $\begin{array}{l}\text { 19. And states of life are ever in change, } \\
\text { 20. Sorrow and misery will leave away } \\
\text { 21. Prosperity and joy won't forever stay }\end{array}$ & وَلا بُوُسنّ عَلَيْلَكَ وَلا رَخَاءُ & 9- وَلا حُزْنْ يَدُومُ وَلا سُرُورٌ \\
\hline 4 & $\begin{array}{l}\text { 22. If your heart is content in its throb and beat, } \\
\text { 23. You share a king in riches, by and by. }\end{array}$ & 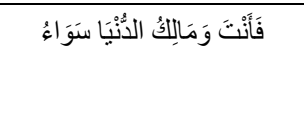 & 10- إذذا مَا كُنْتَ ذَا قَلَبِ قَنُوع ع \\
\hline 4 & $\begin{array}{l}\text { 24. When death shrouds the realm of any soul, } \\
\text { 25. Protection won't dawn from earth or sky }\end{array}$ & فَلا أَرْضُ تَقَيِهِ وَلا سَتَاءُ & 11- وَمَنْ نَزَلَتَتْ بِسَاحَتِهِه المَنَايَا \\
\hline 4 & $\begin{array}{l}\text { 26. And the land of Allah is vast! } \\
\text { 27. Vast for the eye to see. } \\
\text { 28. But when the decree descends, } \\
\text { 29. space constricts tight. }\end{array}$ & إِذَا نَزَلَ القَضَّاء ضَاقَ الفَضَاءُ & 12- وَأَرْضُ اللهِهو وَاسِعَةُ وَلكن. \\
\hline 3 & $\begin{array}{l}\text { 30. So, let the days breach the covenant! } \\
\text { 31. And accept how it must be. } \\
\text { 32. Drink the medicine of the world, } \\
\text { 33. death will still take his right. }\end{array}$ & فَمَا يُغْنِي عَنِ المَوْتِ الدََّ اءُ & 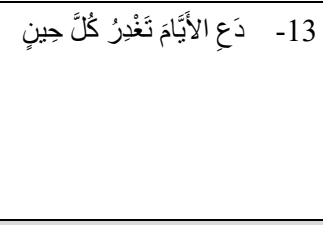 \\
\hline $54 / 65$ & & & \\
\hline
\end{tabular}

The translator and poet participated, collaborated, and assessed the quality of the translated text above, applying Halimah's (2015) grading criteria of ACNCS and Baker's (1992) levels of equivalence when appropriate. It is noteworthy that the higher the intensity of collaboration between the translator and poet and the higher the application of the ACNCS governing criteria is, the better the target text becomes in achieving high levels of approximation to the original poem.

As a starting point, the collaborators on the above English poem tried not only to understand its denotative meanings and connotative associations but also to interpret it in terms of its shape, form, context, purpose and style. With regard to the shape and form of the poem, it has been classically organised in as short as thirteen lines and 123 words, which is an indicator of linguistic conciseness and preciseness. The lines are divided into two hemistichs (شطر), the first half of the line is called الثطر الأول and the second half is called الثطر الثاني and these are separated by a little gap in the text. This feature complies with the classical standard of Arabic poetry.

In terms of context, although the SL poem reflects a period remote in time when Ashshafi'ee as a poet is dead, the significance of the context of the poem is quite alive. This is because the poem carries with it a universal religious message addressed not only to Muslims of the 2 nd Hejri century $/ 8^{\text {th }}$ Gregorian century but all humankind throughout past and future ages. Ashshafi'ee's message is to surrender to no one but to Allah and to accept one's fate with pleasure. The poem uses beautiful imagery, poetic rhyming and rhythm, powerful expressions and imagination to strongly support the poet's message to his audience. It is religiously valid and appreciated making it translationally very challenging. When it comes to rendering it into a TL context, it requires from translators a creative ability to recreate a TT context that is equivalent to that of the original one in its religious and spiritual meanings as well as communicative purpose and stylistic features.

Version B translation above uses a different shape and form from that of the original Arabic poem. It varies from one line of Arabic verse to another. Most of the Arabic lines, for example, were translated into an English couplet, whereas Arabic line 9 was translated into 3 lines and each of the Arabic lines 3,12 and 13 were translated into 4 English lines respectively. The number of lines it used is 33 lines and the number of words it used is 225 English words versus 13 lines and 123 Arabic words used in the ST poem. Although the shape and size of the TT do not look near to that of the ST, it is still appropriate to use in classical English poetry. Translations of lines $(3=5,6,7,8$,$) ,$ $(9=19,20,21),(12=26,27,28,29)$ and $(13=30,31,32,33)$ have deviated from the rest which makes the shape and form of version B seem not only inconsistent and unsystematic but also violates one of the ACNCS criteria and the criterion of equivalence as we will explore below.

The translation is a mix of rhymed and unrhymed lines. Lines 2, 3 and 12 individually rhymed whereas lines 4 and 5, 6 and 7 and 8 and 9 have been rhymed in the form of 4-line stanzas; while lines 1, 10,11 and 13 do not rhyme. This 
unsystematic mix of rhymed and unrhymed lines of verses makes the translation short of being very good. However, to be fair with the poet, all in all it has some kind of rhythm. Based on the grading criteria used in assessing the quality of the translation above, the poet seems to have endeavored to use a literal/faithful method as a global stance and a foreignising approach and a collaborative approach as her local stances. At times she did very well and at times did not do very well.

To illustrate, if we look at lines 1,2,3 and 4, for example, we can see that the poet achieved a degree of positive approximation to the ST in terms of accuracy of meaning, choice of powerful and effective vocabulary and, above all, poetic rhythm and rhyming assonance/sounds. Her choice of the expression "the map of Fate" as a corresponding equivalent to the Arabic expression " القضاء و القدر" seems to have solved so much debate about the exact equivalent of this expression: Is it destiny? Is it doom? Is it qisma/what has been allocated/assigned by Allah? Is it one's lot in life? Is it predestination? etc... Another interesting and debatable expression is her choice of the word 'provision' as a corresponding equivalent to the Arabic word "الرزق" in line 8. Why did she not use one of the following synonyms: livelihood, sustenance, supply, foodstuff, etc. is food for thought. Furthermore, in lines 9,10, 11,12, 15, $16,17,18,22,23,24,25$, the poet also successfully met the grading criteria of accuracy, clarity, naturalness, communicative effectives and stylistic features. Considering the constraints of translating poetry, she has still proven to be faithful to the original text. Her scores in the translation of the Arabic lines 1, 2, 4, 5, 6, 7,8,10, and 11, out of 5 , are 4,5,5,5,4,4,5,4,4 respectively, that is 40 out of 45 which is $89 \%$ approximation of the original text.

Now, let's look at examples where the poet could have done better. If we look at lines $(5,6,7,8 \leftrightarrow 3),(19,20,21 \leftrightarrow 9)$, $(26,27,28,29 \leftrightarrow 12)$ and $(30,31,32,33 \leftrightarrow 13)$, for example, we can see that the poet has failed to use the classical standard poetic couplet where rhyming and rhythmic sounds are in corresponding harmony. Her use of lines 6, 19, 27 and 31 includes unnecessary information and this kind of overtranslation is considered as a weakness in translating any text. Although it is at times allowed in poetry, it is not to that degree where additional complete lines with additional ideas are added. This has naturally affected the validity and reliability of the translation as one can claim it is inaccurate because of the translator being unfaithful to the original text. In these parts of the poem, the poet used a free method where she felt free to add what was necessary for her to boost the meaning at one occasion and rhyming or rhythm in another. Her scores in the translation of the Arabic lines 3, 9, 12, and 13 out of 5, are 3, 3,4,3 respectively, that is 13 out of 20 which is $\mathbf{6 5 \%}$ approximation of the original text. All in all, the total score of the poet's translation of Imam Ashshafi'ee's poem of “الرضا بقضاء الله / "Accepting Fate with Pleasure”, in version B is as follows: 39 Strong points +13 weak points $=54$ points out of the total of 65 that is $83 \%$ approximation of the original poem

Having made a brief critical analysis of the poet's translation of Imam Ashshafi'ee's poem of "الرضا بقضاء الله / "Accepting Fate with Pleasure", we can now either accept Version B as it is or we can go back to the poet and discuss with her the weak points and negotiate whether she could make some changes and improve the quality of the translation and raise the level of approximation to her utmost ability. In our case here, and for the sake of discussion as a translator, the poet was informed about the comments and they were discussed with her. She then willingly agreed to make version $\mathrm{C}$ as in table 3 below:

Table 3. Version C

\begin{tabular}{|c|c|c|}
\hline $\begin{array}{l}\text { Grade } \\
\text { Max:5 }\end{array}$ & "Accepting Fate with Pleasure". & الرضا بقضاء الله \\
\hline $\begin{array}{l}5 \\
22 \mathrm{w}\end{array}$ & $\begin{array}{l}\text { 1.Let the days take their course and make their way, } \\
\text { 2.Accept the map of fate however its route may sway. }\end{array}$ & وَطِبْ نَفْساً إذذا حَكَمَ القَضَّاءُ \\
\hline $\begin{array}{l}5 \\
16 w\end{array}$ & $\begin{array}{l}\text { 3.Do not mourn the distress of the night, } \\
\text { 4.Its trials will pass come daylight. }\end{array}$ & 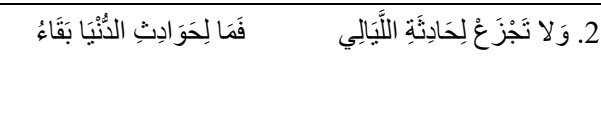 \\
\hline $\begin{array}{l}5 \\
14 w\end{array}$ & $\begin{array}{l}\text { 5.Be a man strong in adversity, } \\
\text { 6.A man of tolerance and integrity. }\end{array}$ & 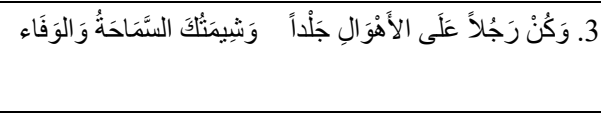 \\
\hline $\begin{array}{l}5 \\
17 \mathrm{w}\end{array}$ & $\begin{array}{l}\text { 7.And if your faults become too many, } \\
\text { 8.And you wish to conceal your shameful tale, }\end{array}$ & 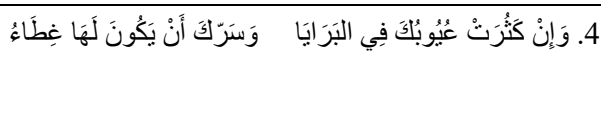 \\
\hline $\begin{array}{l}5 \\
13 w\end{array}$ & $\begin{array}{l}\text { 9.Cloak them with sheer kindness, } \\
\text { 10. It hides blemishes in its veil. }\end{array}$ & 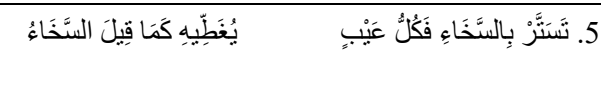 \\
\hline
\end{tabular}




\begin{tabular}{|c|c|c|}
\hline $\begin{array}{l}5 \\
16 w\end{array}$ & $\begin{array}{l}\text { 11. Never let your indignity to enemies seen, } \\
\text { 12. Them mocking your dishonour is a curse. }\end{array}$ & 6. وَلا تُرِ لِلاَعَادِي قَطُ ذُلاً \\
\hline $\begin{array}{l}5 \\
17 \mathrm{w}\end{array}$ & $\begin{array}{l}\text { 13. And seek no forgiveness from the mean, } \\
\text { 14. In flames the parched do die of thirst. }\end{array}$ & 7. وَلا تَزْجُ السَّمَاحَةَ مِنْ بَخِيلٍ \\
\hline $\begin{array}{l}5 \\
17 \mathrm{w}\end{array}$ & $\begin{array}{l}\text { 15. Your provision is written on destiny's page } \\
\text { 16. Its amount in stone, toil as you may. }\end{array}$ & 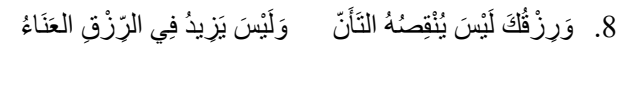 \\
\hline $\begin{array}{l}5 \\
14\end{array}$ & $\begin{array}{l}\text { 17. Sorrow and misery will leave away } \\
\text { 18. Prosperity and joy won't forever stay }\end{array}$ & 9. وَلا حُزْنْ يَدُومُ وَلا سُرُورٌ \\
\hline $\begin{array}{l}4 \\
21 w\end{array}$ & $\begin{array}{l}\text { 19. If your heart is content in its throb and beat, } \\
20 \text {. You share a king in riches, by and by. }\end{array}$ & 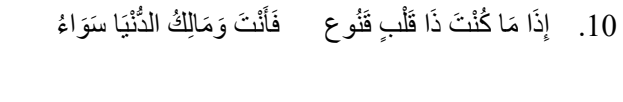 \\
\hline $\begin{array}{l}4 \\
17 w\end{array}$ & $\begin{array}{l}\text { 21. When death shrouds the realm of any soul, } \\
\text { 22. Protection won't dawn from earth or sky. }\end{array}$ & 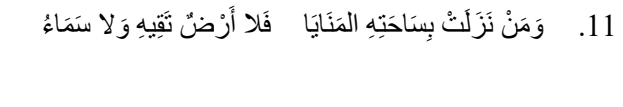 \\
\hline $\begin{array}{l}5 \\
18 w\end{array}$ & $\begin{array}{l}\text { 23. And the land of Allah is vast! But } \\
24 \text {. If the decree descends, space constricts tight. }\end{array}$ & 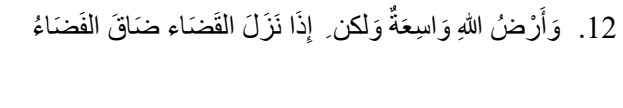 \\
\hline $\begin{array}{l}4 \\
21 w \\
\end{array}$ & $\begin{array}{l}\text { 25. So, let the days breach the covenant! } \\
\text { 26. Drink the medicine of the world, death will still take his } \\
\text { right. }\end{array}$ & 13. دَعَع الأَيَّامَ تَغْدِرُ كُلَّ جِين \\
\hline $62 / 65$ & $95 \%$ equivalence & \\
\hline
\end{tabular}

It is clear that the English version C is quite different from the two versions A and B of the Arabic poem in terms of length, shape and line organisation. Version $\mathrm{C}$ can be seen to sound and read much better as it has been modified and improved in terms of form and content. Regarding the length, shape and size, all Arabic lines, for example, have been translated into equivalent English couplets with reasonable length except the translation of Arabic lines 1 and 13 where the poet favoured rhyming and rhythm to shape and length in the English version. The total number of lines used is now 26, exactly double the number of lines in the Arabic text, and the wordcount is 223 English words versus 13 lines and 123 Arabic words used in the ST poem. Although the shape and size of the TT does not look exactly like that of the ST, it is still appropriate and acceptable to use in classical English poetry, especially for achieving rhyming and rhythm which give the translation a poetic feel and finish to the words as well as a sharper clarity in the emotional effect the poem achieves on the TL reader.

With regard to the content of version $\mathrm{C}$, we can realize that the linguistic structures and the stylistic choices made by both the translator and the poet have helped to achieve accuracy, clarity, naturalness, communicative effects and stylistic features in the end product of the translation. The striking feature of this translation is the cultural and religious dimension that the poet managed to achieve in the final stage of collaboration with the author by not only substituting the word "God" with "Allah" but also by achieving a poetic tone that is lovingly inviting, religiously informative, spiritually inspiring, and emotionally everlasting.

Moreover, the linguistic choices, be they lexical, structural or stylistic, tend to be of a high register which make it the most approximate translation of the ST poem. The ACNCS criteria are nicely met in version C. The poet's total score in the translation of the Arabic poem as shown in the above version C is 62 out of 65 which is an $95 \%$ approximation of the original text at verse level.

After analysing the poem at verse level, it is crucial to examine it as a whole entity against ACNCS criteria. Elements such as structure, flow and the overall feel of the poem, as compared to the ST, are important points to consider in order to give a score that is as accurate as possible.

In this translation, English version $\mathrm{C}$ looks like a typical classically organised rhymed poem, sounds more fluent and is more transparent, communicative and natural. Moreover, it successfully reveals Ashshafi'ee's firm belief and faith in the submission to the ruling of Allah and advocacy for the acceptance of fate with pleasure. This gives the poem the potential to be emotionally felt by the TL reader and be psychologically effective as well as poetically appreciated. This said, although a successful and close approximation of the original poem, version $\mathrm{C}$ has some 
shortcomings that give it a lower score overall than the score it achieved at verse level. This is in regard to certain lines being too long, such as lines 1, 2 and 26, and varying rhyme schemes, rather than one constant scheme, which, in comparison to the ST, together affect how the entire text reads. Therefore, although it achieves 95\% approximation at verse level, version $\mathrm{C}$ achieves a lower $90 \%$ approximation overall: a high grade, nonetheless.

According Bassnett (1980:66), translation of poetry tends to "show faithfulness not to individual words or sentence structures but to a notion of the meaning of the poem in its relationship to its readers. In other words, the poem is perceived as an artefact of a particular cultural system, and the only faithful translation can be to give it a similar function in the target cultural system". The version C translation above is a good example.

The following version of the poem is an example of how classic English poems would look like:

\section{Accepting Fate with Pleasure.}

Let the days take their course and make their way,

Accept the map of fate however its route may sway.

$$
* * * * *
$$

Do not mourn the distress of the night,

Its trials will pass come daylight.

$* * * * * * *$

Be a man strong in adversity,

A man of tolerance and integrity.

$* * * * *$

If your faults become too many,

And you wish to conceal your shameful tale,

Cloak them with sheer kindness,

It hides blemishes in its veil.

$* * * * *$

Never let your indignity to enemies seen,

Them mocking your dishonour is a curse.

And seek no forgiveness from the mean,

In flames the parched die of thirst.

$* * * * *$

Your provision is written on destiny's page

Its amount in stone, toil as you may.

$* * * * * * *$

If your heart is content in its throb and beat,

You share a king in riches, by and by.

When death shrouds the realm of any soul,

Protection won't dawn from earth or sky.

$* * * * *$

And the land of Allah is vast!

But if the decree descends, space constricts tight.

$* * * * *$

So, let the days breach the covenant!

Drink the medicine of the world, death will still take his right. 
Although the English format is acceptable, as an originally authentic Arabic poem, the rhythm, rhyming and elements of meter involved are more clearly pronounced in an Arabic format. Foreignising the shape adds a more distinct effect on the TT reader who can appreciate the traditional roots of the poem in such a subtle but important detail. The shape of poetry carries with it its own historical meanings and culture which are best preserved and honored.

In an Arabic format the poem would be presented as follows:

\section{Accepting Fate with Pleasure}

Let the days take their course and make their way,

Do not mourn the distress of the night,

Be a man strong in adversity,

If your faults become too many,

Cloak them with sheer kindness,

Never let your indignity to enemies seen,

And seek no forgiveness from the mean,

Your provision is written on destiny's page

If your heart is content in its throb and beat,

When death shrouds the realm of any soul,

And the land of Allah is vast! But

So, let the days breach the covenant!

\section{Conclusion}

In this study, the translation of Imam Ashshafi'ee's poem has demonstrated how a collaborative global-local methodological framework resulted in improving the quality of translation. Through steps of constant review and feedback between two parties, a translator and a poet, the translation of the poem became more refined and met higher standards at each stage of the process. This progress can be seen in the differences between the translated texts in versions A, B and C where the translation in version B, graded in compliance with ACNCS criteria, was at an 83\% approximation of the original text and version $\mathrm{C}$ reached an overall of $90 \%$ approximation. The results of this study showcase the benefit of collaboration and how reviewing and discussing the process of translation yields a higher quality level of work.

Although this methodological framework has some limitations, particularly with regard to the availability of English poets, teachers and students can still seek collaboration from English language specialists. It is also hoped that this methodological framework can also be explored and used by those who are interested in not only the translation of Arabic/English poetry and other literary genres, but also other languages and text types, such as technical/scientific, business, legal or even medical texts, that will naturally require relevant language specialists.

It is further recommended for documentation purposes that translated poetry be published bilingually, especially for the bilingual reader. As well as this, the stylistic features of the original poem should be preserved in the translated version.

\section{References}

Ashshafi'ee, I. M. B. I. (2007). Diwan Imam Ashshafi'ee. Alassrya for Publishing and Distributing, Beirut, Lebanon.

Baker, M. (1992/2011). In Other Words: A Coursebook on Translation (2nd ed.). London and New York: Routledge. https://doi.org/10.4324/9780203133590

Bassnett, S. (1980/ 2014). Translation Studies (4th ed.) London and New York: Routledge.

Boase-Beier, J. (2011). 'Poetry'. In Baker, M \& Saldanha, G (ed.), Routledge Encyclopaedia of Translation Studies, (2nd ed.). London and New York: Routledge.

Dickens, J., Hervey, S., \& Higgins, I. (2002/2010). Thinking Arabic Translation. London: Routledge. https://doi.org/10.4324/9780203167120

Halimah, A. M. (2015). Teaching Translation of Poetry: A Collaborative Approach. Journal of English Language \& Literature Studies, 5(1), 26-36. https://doi.org/10.5539/ells.v5n1p26 
Halimah, A. M. (2017). English-Arabic-English Creative Translation: A Practical Course. International Islamic Publishing House, Riyadh, Saudi Arabia.

Halimah, A. M. (2020). English-Arabic-English Translation: A Novel Methodological Framework for the Standardisation of Translation Parameters. Journal of English Language \& Literature Studies, 10(3), 15-30. https://doi.org/10.5539/ells.v10n3p15

Newmark, P. (1988). A Textbook of Translation. Prentice Hall International, London and New York.

Pendlebury, D. (2005). 'Creative Translation' Monograph Series No. 48, the Institute of Cultural Research, Antony Row Ltd. Eastbourne, UK.

Scott, C. (2000). Translating Boudelaire. Exeter, UK: Exeter University Press

Venuti, L. (1995). The Translator's Invisibility: A History of Translation. London and New York: Routledge.

\section{Appendix A: The Five Criteria Model for Evaluating Translation of Poetry}

The following checklist is used by translators while they are engaged in the process and product of translation.

The collaborative translations are to be graded on five-point scale areas. This represents the range of approximate equivalence with the highest degree of 'adequacy and validity' from being a poor translation to being a highly skilled poetry translation. In order of importance, they are as follows:

1. Accuracy is the most important criterion to assess the quality of a translated text. To be accurate is to represent something in accordance with the way it actually is. It refers to the conveyance of the exact and precise meanings of the source text to the target text. To be certain of achieving 'accuracy' in translation, the following questions should be asked: Has the translator been faithful in rendering the exact meanings of the ST to the TT? Has any information mentioned in the ST been missed or omitted? Has any new information been added to the TT? Is there any shade of meaning missing? Has the overall meaning of the ST been transferred successfully to the TT? etc.

2. Clarity in translation is an integral part of the comprehension process of the TT reader. To be clear is to be intelligible without causing the TT reader to exert extra mental effort to understand the content of the TT. In other words, clarity in translation means that the reader can understand the text without any difficulty or the need to refer to any off-site explanation whether inside the text or in a form of footnote. To be certain of achieving 'clarity' in your translation, the following questions should be asked: Is the TT easy to understand? Does it require from the target reader any extra exerted effort to comprehend it? Does it read smoothly and comfortably? Has the ST Message been communicated clearly to the reader of the TT? etc.

3. Naturalness in translation refers to the ability of the creative translator to apply the appropriate natural norms and forms of the Target Language to the source text, which they are translating; be these norms and forms linguistic, sociolinguistic, psychological, sociocultural, communicative or other. To achieve naturalness in your translation the following questions should be asked: Does the TT sound and read like an authentic English text? Does it have the dynamic and idiomatic elements normally used in an authentic English text? Does it have the 'natural wow factor?' etc.

4. Communication in translation, particularly creative translation, involves transferring both the meaning and emotional aspects of the ST to the TT readers as effectively and faithfully as they are communicated to the ST readers in the first place. In other words, a creative translator should ensure that they understand the communicative purpose of the ST and endeavour to achieve it in the TT, be it poetry, novels, short stories, drama, oratory or any other type of literary text. The following questions should be asked to check for this criterion: What is the main communicative purpose of the ST? For example, is it to persuade, to entertain, to delight, to instruct or to inform? Does the TT carry the same meaning and emotional force of the ST?

5. Style in literary texts refers to the linguistic choices the author makes in their writing to tell a narrative, to describe events, objects and characters or to voice out their ideas and views in a manner of their choosing, be it formal, informal, casual or archaic. The author's style in literary texts tends to influence how we interpret the facts and information. Therefore, a creative translator needs to be aware of these features and be able to transfer the stylistic features of the ST to the TT with the same stylistic force used by the ST writer or speaker. In other words, you need to identify the historical, geographical, and cultural 
dimensions of the style used in the ST and endeavour to apply it to the TT with utmost accuracy, clarity, naturalness and communicative force.

\section{Endnote}

مذهب مب الثافعية

\section{Copyrights}

Copyright for this article is retained by the author(s), with first publication rights granted to the journal.

This is an open-access article distributed under the terms and conditions of the Creative Commons Attribution license (http://creativecommons.org/licenses/by/4.0/). 